\title{
KONSEP DIRI PEROKOK DI UNIVERSITAS ISLAM RIAU
}

\author{
Muhd Ar. Imam Riauan ${ }^{1}$ \& Genny Gustina Sari ${ }^{2}$ \\ 1Fakultas Ilmu Komunikasi Universitas Islam Riau; \\ ${ }^{2}$ Fakultas Ilmu Sosial dan Ilmu Politik Unversitas Riau \\ Email: 1imamriauan@comm.uir.ac.id \& 22gennygustina@gmail.com
}

\begin{abstract}
Abstrak
Penelitian ini bertujuan untuk mengetahui bagaimana konsep diri perokok di kalangan dosen Universitas Islam Riau. Konsep diri yang merupakan seperangkat persepsi yang relatif stabil yang dipercaya orang mengenai dirinya sendiri. Penelitian ini menggunakan metode penelitian deskriptif kualitatif dan menggunakan teknik snowball sampling untuk nendapatkan informan yang merokok di Universitas Islam Riau. Dalam penelitian ini, peneliti melakukan wawancara mendalam kepada 10 orang informan untuk menggali konsep diri perokok. Hasil penelitian menunjukkan bahwa terdapat tiga konsep diri perokok di kalangan dosen Universitas Islam Riau. Hasil penelitian ini menujukkan bahwa terdapat tiga konsep diri perokok: 1) Perokok ketergantungan yaitu perokok yang ketergantungan positif, ketergantungan negatif dan ketergantungan adiktif; 2) Perokok Percaya diri memiliki rasa percaya diri dengan menghisap rokok dan memudahkan pergaulannya; 3) Status ekonomi mapan dengan menunjukkan rokok yang dihisap dan kemampuan mereka membeli rokok.
\end{abstract}

Kata Kunci: Konsep diri, perokok, \& ketergantungan

\begin{abstract}
This study aims to find out how smokers' self-concept among lecturers of Riau Islamic University. Self-concept which is a relatively stable set of perceptions that people believe about themselves. This study uses a qualitative descriptive research method and uses a purposive sampling technique to get informants who smoke at the Riau Islamic University. In this study, researchers conducted in-depth interviews with 10 informants to explore the self-concept of smokers. The results showed that there were three selfconcept of smokers among lecturers at the Islamic University of Riau. The results of this study show that there are three self-concept of smokers: 1) Smoker dependence is smokers who are positive dependence, negative dependence and addictive dependence; 2) Smokers Confidence who has confidence by smoking cigarettes and facilitating their relationship; 3) Established economic status by showing cigarettes smoked and their ability to buy cigarettes.
\end{abstract}

Keywords: Self-concept, smoker, \& dependency 


\section{PENDAHULUAN}

Kehidupan sosial merupakan realitas yang disebabkan oleh interaksi manusia dengan simbol-simbol yang berada dalam lingkungan sosial. Interaksi manusia dengan simbol-simbol tersebut menghasilkan produk-produk sosial yang berpengaruh terhadap tatanan sosiologi dalam kelompok dan masyarakat. Pandangan interaksionisme memiliki pandangan bahwa perilaku manusia merupakan produk dan interpretasi mereka atas dunia di sekeliling mereka. Perilaku yang muncul dalam diri manusia tersebut merupakan hasil pemaknaan dari makna yang dipahami oleh manusia terhadap perilaku tersebut. Manusia dalam kehidupan sehari-hari berperilaku atas dasar pemahaman mereka terhadap perilaku yang mereka lakukan. Dengan demikian muncullah perilaku manusia yang merupakan produk dan interpretasi dari perilaku tersebut.

Manusia sebagai makhluk sosial selalu aktif melakukan interaksi dengan lingkungan sosialnya untuk membentuk karakter pribadinya. Melalui proses interaksi manusia dapat memahami konsep diri pribadinya yang kemudian mempengaruhi perilakunya dalam kehidupan sehari-hari.

Menurut Ralph LaRossa dan Donald C. Reitzes (1993) dalam West dan Turner (2009 : 101), individu-individu manusia mengembangkan konsep dirinya dengan melakukan interaksi dengan orang lain, dan konsep diri tersebut memberikan motif sebagai alasan dalam tiap perilaku yang dilakukan oleh manusia.

Untuk memahami konsep diri manusia, maka kita harus mengetahui persepsi manusi tersebut tentang konsep dirinya sendiri. Konsep diri yang merupakan seperangkat persepsi yang relatif stabil yang dipercaya orang mengenai dirinya sendiri (West dan Turner 2009 : 101. Dengan demikian kita perlu memahami persepsi individu-individu untuk memahami konsep diri mereka.

Salah satu perilaku manusia adalah perilaku merokok. Perilaku ini merupakan aktivitas yang cukup berbahaya pada saat ini adalah perilaku merokok. Banyak informasi yang bertebaran tentang bahaya merokok. Bahkan di bungkus rokok dengan jelas disebutkan bahwa merokok dapat menyebabkan penyakit-penyakit yang berat seperti kanker, serangan jantung, impotensi, gangguan kehamilan dan janin. Bahkan ada pesan yang menyampaikan bahwa "Merokok membunuhmu".

Peringatan tersebut pada kenyataannya tidak membuat para perokok menjadi jera dan tetap merokok meskipun menyadari akan bahaya yang mengamcam kesehatan mereka. Para perokok menyadari bahwa merokok itu tidak baik untuk kesehatan dan merasa menyesal sudah terlanjur merokok, akan tetapi di sisi lain mereka juga merasa kesulitan untuk berhenti merokok.

Kenyataan tersebut juga terjadi di Universitas Islam Riau. Universitas Islam Riau (UIR) sendiri merupakan kampus yang bebas dengan asap rokok yang ditandai dengan penghargaan yang didapatkan sebagai kampus yang bebas asap rokok dari Asosiasi Perguruan Tinggi Swasta Indonesia (Aptisi) pada tahun 2015.

Di dalam kampus UIR sendiri masih terdapat kalangan dosen yang merokok di dalam lingkungan kampus yang bebas asap rokok. Seorang dosen yang memiliki pengetahuan yang lebih mapan sendiri ternyata juga meerokok di lingkungan kampus.

\section{KERANGKA TEORI}




\section{Interaksi Simbolik}

Teori interaksi simbolik berakar dan berfokus pada hakikat manusia yang adalah manusia relasional. Setiap individu pasti terlibat relasi dengan sesamanya. Manusia muncul dalam dan melalui interaksi dengan yang di luar dirinya. Interaksi itu sendiri membutuhkan simbol-simbol tertentu. Simbol itu biasanya disepakati bersama dalam skala kecil maupun skala besar. Simbol misalnya bahasa, tulisan dan simbol lainnya yang dipakai bersifat dinamis dan unik (Rohim, 2009 : 76).

Tiga konsep utama dalam teori interaksi simbolik merupakan aspek-aspek yang berbeda dari proses umum yang sama disebut tindak sosial yang merupakan sebuah kesatuan tingkah laku yang tidak dapat dianalisis ke dalam bagian-bagian tertentu (Littlejohn, 2009 : 232). Definisi singkat dari ke tiga ide dasar dari interaksi simbolik, antara lain:

1. Pikiran (Mind) adalah kemampuan untuk menggunakan simbol yang mempunyai makna sosial yang sama, dimana tiap individu harus mengembangkan pikiran mereka melalui interaksi dengan individu lain.

2. Diri (Self) adalah kemampuan untuk merefleksikan diri tiap individu dari penilaian sudut pandang atau pendapat orang lain, dan teori interaksionisme simbolis adalah salah satu cabang dalam teori sosiologi yang mengemukakan tentang diri sendiri (the-self) dan dunia luarnya.

3. Masyarakat (Society) adalah jejaring hubungan sosial yang diciptakan, dibangun, dan dikonstruksikan oleh tiap individu ditengah masyarakat, dan tiap individu tersebut terlibat dalam perilaku yang mereka pilih secara aktif dan sukarela, yang pada akhirnya mengantarkan manusia dalam proses pengambilan peran di tengah masyarakatnya. "Mind, Self and Society" merupakan karya George Harbert Mead yang paling terkenal (Mead. 1934 dalam West-Turner. 2009 : 96), dimana dalam buku tersebut memfokuskan pada tiga tema konsep dan asumsi yang dibutuhkan untuk menyusun diskusi mengenai teori interaksi simbolik.

\section{Konsep Diri}

konsep diri merupakan seperangkat persepsi yang relatif stabil yang dipercaya orang mengenai dirinya sendiri. Tema konsep diri mempunyai dua asumsi tambahan dari Ralph LaRossa dan Donald C. Reitzes (1993) dalam West dan Turner (2009 : 101) yaitu individu-individu mengembangkan konsep diri melalui interaksi dengan orang lain dan konsep diri memberikan motif yang penting untuk perilaku. Menurut Rakhmat (2007: 36) konsep diri merupakan pandangan dan perasaan kita tentang diri sendiri. Persepsi tentang diri yang bersifat psikologis, social, dan fisik.

Aspek fisik menggambarkan bagaimana individu memandang kondisi kesehtan badannya, dan penampilan fisiknya. Aspek psikis meliputu pikiran, perasaan dan sikap terhadap dirinya sendiri. Aspek sosial mencerminkan sejauhmana perasaan mampu berharga dalam lingkup interaksi sosial. (Maria, 2007: 24). Menurut Fitts dalam Efendi (2013) mengungkapkan ada tiga faktor yang mempengaruhi konsep diri yaitu pengalaman, kompetensi, dan aktualisasi diri yang merupakan implementasi dari potensi diri pribadi. 


\section{Merokok}

Merokok merupakan aktivitas yang banyak dilakukan oleh masyarakat di Indonesia pada saat ini. Hal ini terjadi karena barbagai sebab yang kemudian menjadikan masyarakat Indonesia merokok. Harga rokok di Indonesia relatif lebih murah dibandingkan dengan Negara-negara lain seperti Malaysia, Singapura, dan Negaranegara lain di baik Asia, Amerika, maupun di Eropa. Hal ini menyebabkan rokok lebih mudah didapatkan oleh masyarakat Indoensia.

Merokok adalah kegiatan membakar tembakau kemudian dihisap, baik digunakan dengan rokok maupun menggunakan pipa. Temperatur sebatang rokok yang tengah dibakar, dan 30 derajat celcius untuk ujung rokok yang terselip di antara bibir perokok (Istiqomah, 2003: 20). Untuk merokok maka perokok butuh rokok dan korek api untuk membakar rokok tersebut. Rokok tersebut kemudian di bakar dan di hisap untuk mendapatkan rasa dan aroma tembakau dari tiap rokok yang di bakar. Merokok bisa langsung dihisap dengan menggunakan bibir atau melalui media seperti pipa rokok.

Perilaku merokok bagi tiap perokok memiliki tipe yang berbeda-beda. Tomkins Tahun 1996, berpendapat bahwa terdapat 4 tipe perokok. On the basis of this theory we have distinguished four general types of smoking behavior: (1) habitual smoking, (2) positive affect smoking, (3) negative affect smoking, and (4) addictive smoking (Tomkins, 1966: 19).

\section{METODE PENELITIAN}

Peneliti menggunakan pendekatan konsruktivis dalam penelitian ini untuk melihat konsep diri perokok. Dalam menentukan informan, peneliti menggunakan teknik purposif, kemudian melakukan wawancara mendalam kepada 10 orang dosen perokok di Universitas Islam Riau. Berikut kriteria informan dalam penelitian ini :

1. Dosen perokok yang merokok di dalam ruang kerja di lingkungan UIR.

2. Dosen perokok dengan rata-rata minimal 12 batang tiap hari.

3. Dosen yang perokok selama 10 tahun terakhir.

Penelitian ini menggunakan teknik anaslisis data kualitatif dalam menemukan konsep diri perokok. Analisis data kualitatif menurut Bogdan dan Biklen (Moleong, 2009 : 248) merupakan analisis data yang dilakukan dengan jalan bekerja dengan data, mengorganisasikan data, memilah-milahnya menjadi satuan yang dapat dikelola, mensintesiskannya, mencari dan menemukan pola, menemukan apa yang penting dan apa yang dipelajari, dan memutuskan apa yang dapat diceritakan kepada orang lain.

\section{PEMBAHASAN}

\section{Hasil Penelitian}

\section{a. Konsep Diri Individu dalam Perilaku Merokok}


Konsep diri yang merupakan seperangkat persepsi yang relatif stabil yang dipercaya orang mengenai dirinya sendiri. Tema konsep diri mempunyai dua asumsi tambahan dari Ralph LaRossa dan Donald C. Reitzes (1993) dalam West dan Turner (2009 : 101) yaitu individu-individu mengembangkan konsep diri melalui interaksi dengan orang lain dan konsep diri memberikan motif yang penting untuk perilaku.

Berdasarkan hasil penelitian dan wawancara, maka penelitian menemukan bahwa perokok memiliki konsep diri ketergantungan terhadap rokok. Ketergantungan terhadap rokok ini dibagi menjadi dua, ada yang ketergantungan dengan rokok itu sendiri dalam wujudnya karena tidak jika tidak merokok dan harus menghisap rokok. Dan ada yang ketergantungan dengan rokok untuk tujuan-tujuan tertentu seperti menghilangkan stres, menghilangkan suntuk, menenangkan diri, membangkitkan semangat kerja, berpikir, merenung, dan menumbuhkan ide-ide kreatif sehingga menghasilkan karya-karya yang dapat dihargai dan bermanfaat demi pengembangan diri.

Berikut hasil wawancara peneliti dengan informan penelitian mengenai konsep diri mereka sebagai perokok:

Dengan merokok, dapat membangkitkan otak untuk lebih bekerja, menghilangkan kebuntuan bagi pecandu rokok. Dalam bekerja, merokok dapat menghilangkan negatif thingking. Dengan merokok, dapat menenangkan saat gelisah. (Wawancara Informan, Rabu 10 Mei 2018)

Rokok begitu berperan, hanya sebagai penghilang suntuk. Menghilangkan suntuk, tekanan pekerjaan, mencari inspirasi. (Wawancara Informan, 27 Maret 2018)

Merokok juga dapat menjadi media untuk berpikir dan merenung, banyak ideide kreatif yang muncul ketika kita merokok sambil berpikir dan merenung. Pemikiran-pemikiran dapat muncul ketika merokok. (Wawancara Informan, Rabu 10 Mei 2018)

Rokok menjadi mood booster untuk bekerja, berpikir, dan berbagai aktivitas lainnya. Apapun kerjaan kalau ga menggunakan rokok, susah untuk dikerjakan. (Wawancara Informan, Rabu 10 Mei 2018)

Rokok itu sebuah media untuk melahirkan ide, Mencari inspirasi, dengan merokok maka akan melahirkan ide-ide baru. (Wawancara Informan, 7 Mei 2018)

Merokok merupakan cara menata pikiran, menata pembicaraan untuk dapat fokus ketika berkomunikasi dan beraktivitas. (Wawancara Informan, 16 Februari 2018)

Rokok dan merokok itu dapat menghilangkan stres, mencari inspirasi. Rasa nya pikiran jadi rileks, tenang. Mencari inspirasi, menghilangkan stres. Sebagai penghilang stres, berpikir, mencari inspirasi. (Wawancara Informan, 8 Maret 2018)

Dari segi kesehatan menurut saya ada nilai tambah dari diri saya, dari segi ekonomi saya sudah tersugesti dari pengalaman saya, saya bisa melahirkan ide baru, memang akan menguras uang tentunya. (Wawancara Informan, 7 Mei 2018) 
Hasil wawancara di atas menunjukkan bahwa perokok merasakan ketergantungan dengan rokok itu sendiri dalam menghadapi sebuah masalah dalam pekerjaan yang mereka lakukan. Mereka menganggap bahwa rokok dapat mendukung kinerja agar bekerja dengan maksimal. Merokok memperkuat semangat dalam bekerja sehingga menjadikan pikiran lebih kreatif dan menghasilkan ide kreatif dalam bekerja.

Kejenuhan dan kebuntuan dalam bekerja menjadi hilang dengan merokok. Hal ini kemudian menyebabkan pikiran menjadi tenang dan kemampuan berpikir secara jernih meningkat dan mampu membantu kembali melakukan aktivitas dalam bekerja. Hal tersebut kemudian menunjukkan bahwa konsep diri perokok sebagai perokok ketergantungan dalam menghilangkan efek negatif yang berupa stress dan suntuk serta kejenuhan alam menghadapi masalah dalam hidup.

Selain itu, informan mengatakan bahwa rokok merupakan relaksasi yang menyebabkan kita tidak stress. Rokok juga menghilankan beban, dan menenangkan pikiran agar merasa lebih baik dalam hidup. Rokok menjadi solusi sebagai teman penghilang stres. Jika stress sudah melanda, maka rokok menjadi obat untuk menyembuhkannya.

Makna merokok adalah kebutuhan. Ga tahan kalau ga merokok. Separuh beban hidup hilang kalau merokok. Merokok itu adalah relaksasi, sehingga kita tidak stres. (Wawancara Informan, Rabu 10 Mei 2018)

Kemudian merokok adalah relaksasi dari stress yang kemudian mampu memunculkan kembali semangat untuk bekerja. (Wawancara Informan, 16 Februari 2018)

Rokok juga berfungsi menghilangkan beban, menenangkan pikiran (Wawancara Informan, 8 Maret 2018)

Merasa lebih baik ketika merokok. (Wawancara Informan, 10 Mei 2018)

Rokok dan merokok itu dapat menghilangkan stres, mencari inspirasi. Rasa nya pikiran jadi rileks, tenang. Mencari inspirasi, menghilangkan stres. Sebagai penghilang stres, berpikir, mencari inspirasi. (Wawancara Informan, 8 Maret 2018)

Menurut saya rokok dan merokok itu satu paket ya, teman penghilang stres membuat lebih rileks. Jika merokok pastinya pikiran tenang. Menghilangkan stres dan merokok itu hanya untuk merilekskan pikiran. (Wawancara Informan, 7 Mei 2018)

Jika tidak merokok, bagi saya tidak ada pengaruhnya, biasa saja. Namun jika sedang stres tidak merokok akan merasa sakau. (Wawancara Informan, 8 Maret 2018)

Karakter yang menurut saya ya palingan hanya sulit menghilangkan kebiasaan jika stres, suntuk, maka akan merokok. (Wawancara Informan, 7 Mei 2018)

Selanjutnya, konsep diri yang muncul dari perilaku merokok adalah rokok merupakan simbol orang kaya berduit. Orang yang merokok identik dengan orang yang memiliki uang karena mampu membeli rokok yang harganya semakin tinggi di Indonesia. Orang yang merokok dianggap orang yang sudah bekerja dan mampu 
menghasilkan uang karena biaya merokok tidaklah murah. Hal ini menandakan bahwa seorang perokok sudah mampu menghasilkan uang sendiri mampu membeli rokok.

Hal tersebut sesuai dengan hasil wawancara informan yang menyatakan bahwa merokok memang memerlukan biaya yang cukup besar dan menguras uang yang dimiliki. Akan tetapi dengan merokok mereka merasakan bahwa ada nilai tambah yang didapatkan sehingga mendukung kreativitas bekerja dan memberikan nilai tambah bagi diri mereka. Berikut kutipan hasil wawancara dengan informan:

Selain itu merokok juga sebagai simbol orang kaya/berduit, Apalagi sekarang di Indonesia rokok juga semakin mahal rokok menunjukkan kelas ekonomi sang perokok tersebut. Boleh merokok asalkan sudah bisa cari uang sendiri. (Wawancara Informan, 10 Mei 2018)

Dari segi kesehatan menurut saya ada nilai tambah dari diri saya, dari segi ekonomi saya sudah tersugesti dari pengalaman saya, saya bisa melahirkan ide baru, memang akan menguras uang tentunya. (Wawancara Informan, 7 Mei 2018)

Kemudian, konsep diri selanjutnya adalah percaya diri. Dengan merokok, perokok merasa lebih percaya diri dalam bergaul dengan teman-teman atau orang-orang baru yang mereka temui. Dengan merokok, perokok dapat lebih tenang dalam berkomunikasi. Suasana menjadi lebih cair sehingga komunikasi pun bisa mencair. Merokok dianggap menjadi media untuk bergaul baik di grup perokok, maupun di grup yang tidak merokok. Dengan demikian mereka merasa perlu untuk merokok agar pergaulan menjadi lancar.

Merokok adalah simbol pergaulan, karena rokok menjadi bahasa pergaulan untuk mencairkan komunikasi antara 1 orang dengan orang lainnya. (Moris Adidi, 10 Mei 2018) Merokok juga sebagai media untuk mencairkan suasana. (Setio Utomo, Rabu 10 Mei 20178) Merokok adalah pergaulan. Sebagai media untuk bergaul baik dengan grup perokok maupun yang tidak merokok. (Wawancara Informan, 16 Februari 2018)

Merokok merupakan cara menata pikiran, menata pembicaraan untuk dapat fokus ketika berkomunikasi dan beraktivitas. (Wawancara Informan, 16 Februari 2018)

"Konsep diri orang merokok biasa aja, ga' ada yang spesial. Orang merokok biasanya mencoba membaur, karena rokok menjadi media untuk pergaulan. Bisa dekat dengan orang tanpa harus berkata-kata. Bagi yang susah ngomong malah rokok dapat menjadi alasan untuk berbaur. Menurut kami tidak merokok itu lebih bersih, kalau merokok itu kusam." (Wawancara Informan, 16 Februari 2018)

Saya tidak perokok aktif, saya merokok hanya tergantung mood misalnya sedang suntuk. Tidak ketergantungan, hanya sekali-sekali. Sebagai seorang pemikir jika merokok, berarti ada yang sedang dipikirkan jika merokok. Menurut saya karakter perokok biasa biasa saja, dan karakter perokok juga biasa-biasa saja. Terkadang beban hidup orang berbeda-beda. (Wawancara Informan, 27 Maret 2018) 
Di sisi lain merokok menjadi sebuah kebutuhan yang menjadi candu bagi para perokok. Beberapa informan merasa tidak sanggup kalau tidak merokok. Mereka tidak dapat menahan untuk tidak merokok sehingga menjadikan mereka terusmenerus merokok dalam kehidupan sehari-hari. Bahkan merasakan bahwa beban hidup seakan hilang separuhnya karena hisapan rokok yang dikonsumsi.

Beberapa perokok merasakan bahwa diri mereka sudah terlanjur merokok dan sangat susah untuk berhenti merokok. Mereka pasrah dengan keadaan dan tetap merokok dalam kesehariannya meskipun menyadari bahwa rokok tersebut memiliki efek yang negatif.

"Kita sadar bahwa Merokok tidak sehat, terlanjur jadi perokok dan susah berhenti, mau gimana lagi?". (Wawancara Informan, Rabu 10 Mei 2018)

Makna merokok adalah kebutuhan. Ga tahan kalau ga merokok. Separuh beban hidup hilang kalau merokok. Merokok itu adalah relaksasi, sehingga kita tidak stres. (Wawancara Informan, Rabu 10 Mei 2018)

\section{Pembahasan Penelitian}

Berdasarkan hasil penelitian, peneliti mengkategorisasikan konsep diri dalam perilaku merokok menjadi tiga kategori konsep diri: 1) Ketergantungan Rokok; 2) Percaya Diri; 3) Ekonomi Mapan. Berikut pembahasannya:

\section{a. Ketergantungan Rokok}

Ketergantungan terjadi pada diri manusia baik secara fisik ampun secara psikologis. Ketergantungan rokok yang dialami oleh perokok bisa dibagi menjadi dua yaitu ketergantungan fisik dan psikologis. Secara fisik menurut Suarya, dkk (2016: 26) terjadi ketika tubuh melakukan penyesuaian terhadap suatu zat sehingga jaringan tubuh menerimanya sebagai fungsi normal. Faktor yang menyebabkan ketergantungan salah satunya adalah reinforcement positif dan reinforcement negatif. Reinforcement positif adalah kejadian atau item yang menyebabkan seseorang memperoleh kenikmatan setelah melakukan suatu tindakan. Reinfrocement negatif adalah berkurang atau hilangnya perasaan tidak nyaman setelah suatu tindakan. (Suarya, 2016: 26)

Berdasarkan temuan penelitian ini, peneliti mengkategorikan tiga tipe ketergantungan merokok:

\section{1) Ketergantungan Positif}

Merokok menyebabkan ketergantungan terhadap rokok itu sendiri. Para perokok memiliki kecenderungan untuk menghisap rokok sebagai media untuk melakukan aktivitas dalam kegiatan sehari-hari. Ketergantungan positif merujuk pada ketergantungan terhadap rokok untuk memicu tumbuhnya hal-hal positif dalam diri perokok. Para perokok membutuhkan rokok untuk menciptakan efek positif dalam diri mereka.

Perokok membutuhkan rokok untuk menyebabkan relaksasi bagi diri mereka. Dengan merokok pikiran menjadi rileks dan tidak stres. Selama merokok, pikiran menjadi lebih tenang semangat dalam bekerja. Merokok menjadikan diri perokok 
menjadi lebih baik dalam hidup karena merokok dirasakan memiliki efek positif bagi para perokok.

Hal ini kemudian akan berdampak positif bagi diri perokok ketika mampu menyelesaikan pekerjaan yang menjadi tanggungjawab mereka dalam dunia kerja. Rokok menjadi mood booster Ketika suatu pekerjaan sangat melelahkan dan mengalami kebuntuan. Hal ini terjadi karena para perokok merasa susah untuk bekerja kalau tidak dilakukan secara bersamaan dengan merokok.

\section{2) Ketergantungan Negatif}

Ketergantungan negatif adalah ketergantungan terhadap rokok untuk mengurangi atau bahkan menghilangkan perasaan negatif yang ada pada diri perokok. Para perokok menghisap rokok agar merasakan ketengan dalam diri mereka. Perokok menghisap rokok untuk menghindari suasana negatif yang ada pada diri perokok.

Ketergantungan negatif ini membantu para perokok untuk menghilangkan stres, menghilangkan suntuk, menenangkan diri, membangkitkan semangat kerja, membantu meningkatkan kemampuan berpikir, merenung dan menumbuhkan ideide kreatif sehingga menghasilkan karya-karya yang dihargai dan bermanfaat bagi pengembangan diri. Merokok dapat membangkitkan kinerja otak untuk lebih bekerja dan menghilangkan kebuntuan dalam bekerja. Pekerjaan yang tadinya berat menjadi lebih ringan.

Mudahnya pekerjaan atau hilangnya perasaan negatif terkadang menjadi realitas semu yang dirasakan oleh para perokok. Pada kenyataannya ternyata masih banyak perokok yang kemudian tidak menyelesaikan pekerjaan apapun selain merasakan asap rokok yang mereka hisap dari tiap batang rokok yang dibakar. Pekerjaan yang harusnya selesai tidak pernah selesai karena hanya menghisap rokok. Akan tetapi, di sisi lain memang beberapa perokok merasakan bahwa merokok dapat menghilangkan suntuk dan menghilangkan tekanan pekerjaan sehingga setelah merokok, maka pekerjaan menjadi lebih mudah untuk dikerjakan.

\section{3) Ketergantungan adiktif}

Ketergantungan adiktif merupakan ketergantungan yang paling tinggi tingkat kebutuhannya terhadap rokok. Para perokok adiktif membutuhkan rokok jauh lebih banyak daripada perokok positif dan perokok negatif. Perokok adiktif akan segera sadar ketika dia tidak merokok dan merasakan ada yang salah ketika tidak merokok dan segera membakar rokok. Semua perokok berpotensi untuk menjadi perokok adiktif apabila gagal memngontrol jumlah rokok yang dihisap.

Perokok adiktif susah untuk berhenti meskipun dalam diri mereka merasakan perasaan ingin berhenti merokok. Meskipun pada kenyataannya perokok merasa sangat sulit bahkan tidak mampu untuk berhenti untuk merokok. Zat adiktif yang terdapat dalam rokok mempengaruhi kondisi fisik para perokok sehingga tubuh membutuhkan zat yang terkadung dalam rokok tersebut. Kesadaran akan bahaya rokok yang dapat menyebabkan masalah kesehatan diabaikan oleh perokok adiktif karena meraka tidak mampu untuk berhenti merokok. Perokok merasa pasrah akan 
kondisi tersebut karena sudah terlanjur menjadi perokok dan akhirnya mereka terus menurus merokok.

\section{Percaya diri}

Konsep diri yang kedua adalah percaya diri. Para perokok merasa diri mereka lebih percaya diri dengan merokok. Merokok dijadikan simbol pergaulan yang memediasi perokok untuk percaya diri dalam bergaul. Rokok digunakan untuk membuka percakapan dengan orang lain yang baru dikenal maupun teman yang sudah lama dikenal.

Perokok yang ketergantungan karena kebiasan merokok merupakan karakter perokok yang menjadikan rokok sebagai media agar aktivitas pergaulan semakin mudah dilakukan. Kepercayaan diri yang tumbuh tersebut kemudian memudahkan perokok untuk membaur, membangun komunikasi dengan orang lain. Rokok mencairkan suasana sehingga komunikasi menjadi lebih lancar.

Selain itu percaya diri muncul karena rokok dapat menata pikiran para perokok. Dengan merokok pikiran tertata dengan baik. Sehingga ini memudahkan mereka dalam berkomunikasi. Pesan yang disampaikan dapat disampaikan dengan baik karena tertatanya pikiran mereka karena rokok. Oleh sebab itu para perokok akan lebih mudah untuk bergaul dengan orang lain.

Dengan merokok, perokok merasa lebih percaya diri dalam bergaul dengan teman-teman atau orang-orang baru yang mereka temui. Dengan merokok, perokok dapat lebih tenang dalam berkomunikasi. Suasana menjadi lebih cair sehingga komunikasi pun bisa mencair. Merokok dianggap menjadi media untuk bergaul baik di grup perokok, maupun di grup yang tidak merokok. Dengan demikian mereka merasa perlu untuk merokok agar pergaulan menjadi lancar.

\section{Ekonomi mapan}

Konsep diri yang ketiga adalah ekonomi mapan. Ekonomi mapan menunjukkan bahwa perokok merasa diri mereka memiliki kemampuan ekonomi yang lebih baik. Hal ini disebabkan karena rokok sendiri memiliki harga yang tidak murah bahkan bisa dikatakan mahal. Sebatang rokok seharga Rp.1000 s/d Rp.2000 yang apabila dihisap sahari satu bungkus akan menghabiskan minimal 12 batang dan itu seharga Rp.24.000. Perokok adikif biasanya menghabiskan rata-rata 2 bungkus rokok atau sebanyak 24 batang tiap harinya. Hal ini menunjukkan bahwa para perokok memiliki ekonomi yang lebih baik dibandingkan dengan mereka yang tidak merokok.

Pendapati ini kemudian tentunya tidak dapat menjadi indikator dalam kemapanan hidup seseorang. Akan tetapi dengan mahalnya harga rokok tersebut, para perokok merasakan bahwa rokok yang dihisap menunjukkan kelas ekonomi mereka. Harga rokok yang mahal kemudian membuat mereka merasakan sebagai orang yang ekonominya mapan.

\section{KESIMPULAN}


Berdasarkan hasil penelitian di a tas, maka peneliti menyimpulkan bahwa konsep diri dalam diri perokok dapat dikategorisasikan sebagai berikut: 1) Perokok ketergantungan yaitu perokok yang ketergantungan positif, ketergantungan negatif dan ketergantungan adiktif; 2) Perokok Percaya diri memiliki rasa percaya diri dengan menghisap rokok dan memudahkan pergaulannya; 4) Status ekonomi mapan dengan menunjukkan rokok yang dihisap dan kemampuan mereka membeli rokok.

Merokok dapat menimbulkan kecanduan adiktif apabila tidak dikontrol penggunaannya. Terutama jika tingkat stres yang dimiliki perokok ketergantungan non adiktif sangat tinggi. Semakin tinggi tingkat stres yang dirasakan maka akan semakin banyak batang rokok yang akan dihisap oleh perokok. Banyak rokok yang dihisap akan meningkatkan kadar zat adiktif dari rokok di dalam tubuh perokok sehingga perokok akan meraskan pengaruh fisik apabila zat adiktif yang dikandung oleh rokok berkurang. Hal ini kemudian menimbulkan ketergantungan adiktif yang tidak bisa dihindari oleh para perokok.

\section{DAFTAR PUSTAKA}

Ardianto, Elvinaro \& Bambang Q-Anees. 2009. Filsafat Ilmu Komunikasi. Bandung: Simbiosa Rekatama Media.

Arifin, Anwar. 1994. Strategi Komunikasi Sebuah Pengantar Ringkas. Bandung: Armico.

Cangara, Hafied, 2005. Pengantar Ilmu Komunikasi. Jakarta: PT RajaGrafindo Persada.

Efend, A.M. 2013. Hubungan antara Konsep Diri dan Pola Asuh Orangtua dengan Konformitas Santri. Thesis: Universitas Muhammadiyah Surakarta.

Fisher, B. Aubrey. 1978. Teori-teori Komunikasi (Penyunting Jalaluddin Rakhmat), Bandung: Remadja Rosdakarya.

Herdiansyah, Haris. 2011. Metodologi Penelitian Kualitatif Untuk Ilmu-Ilmu Sosial. Jakarta: Selemba Humanika.

https://www.riau.go.id/home/content/2015/04/07/3270-uir-raih-penghargaankampus-bebas-asap-rokok(diakses pada 24 Maret 2016)

Kuswarno, Engkus. 2008. Etnografi Komunikasi Pengantar dan Contoh Penelitiannya. Bandung: Widya Padjadjaran.

Littlejohn, Stephen W \& Karen A. Foss. 2009. Teori Komunikasi. Terjemahan Mohammad Yusuf Hamdan. Jakarta: Salemba Humanika.

Moleong, Lexy J. 2000. Metodologi Penelitian Kualitatif. Bandung: PT. Remaja Rosdakarya.

, Lexy J. 2009. Metodologi Penelitian Kualitatif. Bandung: Remaja Rosdakarya.

, Lexy J. 2005. Metodologi Penelitian Kualitatif. Bandung: PT. Remaja Rosdakarya.

Mulyana, Deddy. 2008. Metodologi Penelitian Kualitatif: Paradigma Baru Ilmu Komunikasi dan ilmu sosial lainnya. Bandung: Remaja Rosdakarya. 
Laturrakhmi,Yun Fitrahyati. 2015, Memahami Makna Simbolisasi Kultural Dan Sosial Perilaku Merokok: Studi Kualitatif Pada Masyarakat Pedesaan DalamUpaya Perumusan Model Kampanye Anti-Rokok. Prosiding Simposium Nasional Komunikasi Kesehatan 2015, Bandung: LP3 Fikom Unpad

Liliweri, Alo. 2011. Dasar-Dasar Komunikasi Kesehatan. Yogyakarta: Pustaka Pelajar.

Lloyd,Kevin Lucas Barbara. (1999),Adolescent smoking: the control of mood and body imageconcerns",Health Education,Vol. 99 Iss 1 pp. 17 - 26

Rakhmat, Jalaludin. 2007. Psikologi Komuinikasi. Bandung: Remaja Rosda Karya

Reimondos, Anna, dkk. (2010), Merokok dan Penduduk Dewasa Muda di Indonesia. Jakarta: Pusat Penelitian Kesehatan Universitas Indonesia

Rohim, Syaiful. 2009. Teori Komunikasi Perspektif, Ragam, \& Aplikasi. Jakarta: Rineka Cipta.

Satori, Djam'an \& Aan Komariah. 2009. Metodologi Penelitian Kualitatif. Bandung: Alfabeta.

Turner, R. W. (2012). Pengantar Teori Komunikasi Analisis dan Aplikasi. Introducing Communication Theory: Analysis and Application. Jakarta: Salemba Humanika.

West, Richard \& Lynn H. Turner. 2009. Pengantar Teori Komunikasi: Analisis dan Aplikasi. Terjemahan Maria Natalia Damayanti Maer. Jakarta: Salemba Humanika.

Wolburg, Joyce M. (2004),The need for new anti-smoking advertising strategies that do not provoke smoker defiance, JournalofConsumer Marketing,Vol. 21 Iss 3 pp. $173-174$. 